\title{
Do Multinational Enterprises Substitute Parent Jobs for Foreign Ones? Evidence from Firm Level Panel Data
}

\author{
By: Jozef Konings and Alan Murphy
}

Working Paper No. 371

April 2001 


\section{Non-Technical Summary}

The increased globalization of the world economy has stirred the fear that domestic employment will be relocated to the lower wage countries. The signing of the NAFTA agreements in the US and the liberalization of the economies in Central and Eastern Europe, which resulted in the Association Agreements with the EU, have contributed to this fear. This has driven an ongoing debate about the role of international trade in contributing to labor market distortions. However, there is still no consensus about the extent to which globalization has mattered in affecting the demand for home jobs.

One of the most obvious channels through which home jobs may be affected is the employment allocation of multinational enterprises (MNEs). However, surprisingly little work has been done on how labor demand decisions of MNEs with affiliates in different locations are driven by labor cost differentials. This paper uses data on over 1,200 European MNEs and their affiliates to analyze how parent employment may be relocated to their subsidiaries in response to relative wage differentials between the parent company and its affiliate(s). Our data set contains MNEs with affiliates that are located in the EU, in Central and Eastern Europe or both and it covers the period between 1994-98, a period in which worldwide foreign direct investment has grown rapidly.

Our main findings can be summarized as follows: (i) We find that on average relocation of parent jobs to subsidiaries of MNEs does occur. However, contrary to the popular belief, this relocation effect is mainly taking place between parents and their EU based subsidiaries, not between parents and their low cost Central and East European based subsidiaries. (ii) This relocation of jobs between parent firms and its affiliate(s) is mainly driven by firms that are operating in the manufacturing sector. For firms operating in the service sectors we find no evidence of employment relocation, while for firms that operate in the wholesale sectors (distribution) we find relocation to the lower wage subsidiaries in Central and Eastern Europe.

The results of this paper suggest that foreign direct investment in Central and Eastern Europe is mainly taking place to obtain market access and to achieve a strategic position in the emerging markets, rather than to exploit cheap labour costs. In contrast, foreign direct investment within the EU seems to be driven by labour cost differences. Relocation seems to occur mainly between parent firms and their 
subsidiaries within the EU. This suggests that the opening of Central and Eastern Europe does not pose a threat to job opportunities in the EU.

\begin{abstract}
This paper analyzes the demand for labor by home multinational enterprises (MNEs) in Europe. To this end we use a unique firm level panel data set of more than 1,200 European multinational enterprises and their subsidiaries that are located in either the European Union, Central and Eastern Europe or both.

We investigate whether employment in the MNEs' subsidiaries are substitutes for home employment or in other words we investigate whether European MNEs can easily relocate employment between the parent and their daughter(s).

Our main findings can be summarized as follows: (i) We find evidence for substitution effects between parent and foreign employment. A decline of $10 \%$ in MNE affiliate's wage costs is associated with a decline in parent employment of between $1.5 \%$ and $2 \%$ on average. (ii) This effect is mainly driven by firms that operate in the manufacturing sector. Moreover, the substitution effects mainly take place between EU parents and their affiliates located within the EU, rather than affiliates located in Central and Eastern Europe. (iii) We also report results for the non-manufacturing firms, where we find no substitution effects between parents and daughters in the service sectors, while we do find positive substitution effects between parents and their affiliates in Central and Eastern Europe for the firms operating in the wholesale trade and construction sectors.

Our results suggest that on average the competition from low wage countries in Central and Eastern Europe did not contribute to a relocation of domestic jobs to Central and Eastern Europe. Substitution effects do take place, however, they mainly occur between parent firms and their affiliates that are located in the European Union.
\end{abstract}

JEL classification: $\quad$ F23, J23

Key words: Relocation, Multinational Enterprises, Labor Demand 


\section{Introduction}

The increased globalization of the world economy has stirred the fear that domestic employment will be relocated to the lower wage countries. The signing of the NAFTA agreements in the US and the liberalization of the economies in Central and Eastern Europe, which resulted in the Association Agreements with the EU, have contributed to this fear. This has driven an ongoing debate about the role of international trade in contributing to labor market distortions ${ }^{\square}$ However, there is still no consensus about the extent to which globalization has mattered in affecting the demand for home jobs. One of the most obvious channels through which home jobs may be affected is the employment allocation of multinational enterprises (MNEs). However, surprisingly little work has been done on how labor demand decisions of MNEs with affiliates in different locations are driven by labor cost differentials. This paper uses data on over 1,200 European MNEs and their affiliates to analyze how parent and subsidiary employment may be substituted.

From figures 1 to 3, which show the evolution of foreign direct investment (FDI) in the OECD, it is clear that since the early 1990s both inflows and outflows of FDI in the OECD regions have increased rapidly. This rapid growth has occurred in both the industrialized countries and the less developed ones. In the context of the liberalization of CEE, figure 3 shows that in a period of less than 10 years there has been a seven fold increase in FDI inflows into Central and Eastern Europe ${ }^{\text {}}$. In this paper we will make a distinction between subsidiaries located within the EU versus those located in CEE, to assess whether competition from low wage countries has contributed to the relocation of employment.

Our main findings can be summarized as follows: (i) We find evidence for substitution effects between parent and foreign employment. However, contrary to the popular belief, this substitution effect is mainly taking place between parents and their EU based subsidiaries. This result, though, is consistent with what theory would predict. (ii) The substitution between parent and foreign employment depends on whether the firms operate in the manufacturing or the non-manufacturing sector. For manufacturing firms the substitution effect is mainly taking place between parent and

\footnotetext{
${ }^{1}$ For recent overviews see Johnson and Stafford (1999) and Slaughter (1998).

${ }^{2}$ Bevan and Estrin (2000) analyze the determinants of FDI in Central and Eastern Europe where the role of EU accession in FDI flows is studied.
} 
foreign employment in subsidiaries located in the EU, while for non-manufacturing firms the substitution effect in mainly taking place between parent and foreign employment in subsidiaries that are located in CEE. However, this effect is driven by firms operating in the wholesale trade and construction sectors. For service firms we find no substitution effects.

The structure of this paper is as follows. In the next section we provide a literature background, while in the third section we provide a theoretical and econometric framework. The fourth section discusses the data set that we use and the fifth section reports estimates of labor demand functions for parent companies. Section six performs some robustness checks of our analysis. In section seven we give our conclusions.

\section{Related Literature}

There are three broad sets of studies that look at how international trade affects labor market outcomes.

The first set has focused on how much international trade has contributed to changing wages and employment. Freeman and Katz (1991) report a significant correlation between import volumes and employment plus a statistically significant, but small, relation between imports and wages. Revenga (1992) using industry prices and source-weighted industry exchange rates finds that changes in import prices have had a significant effect on both employment and wages in US manufacturing. While Feenstra and Hanson (1995) formulate a model of international outsourcing of production to assess the impact of relocation by marginal production activities from the US. They find evidence that outsourcing is raising US and foreign wage inequality. Earlier studies such as Grossman (1986) conclude that foreign competition is not responsible for employment loss in the US steel industry. While Grossman (1987) for nine manufacturing industries between 1969-79 find import competition affected employment in only one industry and wages in only two industries.

The second set of studies initiated by Bhagwati (1991) has focused on explaining the increased wage inequality through international trade and technological progress. He concludes that the trade focused explanation for rising U.S. wage inequality is not very plausible. Further research by Sachs and Shatz (1994) separating the effects of computer prices from other sectors, found that for noncomputer sectors international trade contributed to increasing US wage inequality. 
Leamer (1998) looks at wage inequality driven by product price shifts during the three periods 1960s, 1970s and 1980s for manufacturing. He concludes that increases in wage inequality during the 1970 s were caused by product price changes. Furthermore, Krueger (1997) indicates a positive correlation between product-price increases and skill intensity. Thus she concludes that the magnitude of product price increases and wage changes for skilled and unskilled workers are roughly comparable. Baldwin and Cain (2000) find that both international trade and technological progress have contributed to increased wage inequality during the 1980s and 1990s. In contrast, Lawrence and Slaughter (1993) find no clear evidence that the raising of the relative price for skilled-labor-intensive products has caused increasing US wage inequality. While Harrigan and Balaban (1997) find that the main component behind changing relative-prices which contribute to rising wage inequality was a substantial increase in the price of non-traded products relative to traded products. Finally, Slaughter (2000) cannot find strong evidence that international trade has mattered in explaining increased wage inequality in the US.

A third set of studies has received remarkably little attention in the literature so far, it deals with the question of how multinational enterprises may relocate part or all of their home employment to other countries.

Most papers dealing with these issues, however, have used sector level data to address questions of employment allocation of MNEs. Yet, within the same sector domestic and foreign firms are both usually active, hence sector level data may not take this firm level heterogeneity within sectors into account. This suggests that the right unit of analysis should be the MNE, rather than a sector in which both domestic firms and MNEs operate. Slaughter (2000) uses US sector level data to assess the effects of multinational transfers on labor demand. MNE transfer tends to have small, imprecisely estimated effects on US relative labor demand, which is inconsistent with substitution of unskilled labor between parent firms and their affiliates. Brainard and Riker (1997) use firm level data and find weak substitution effects between parent firms and subsidiaries that are located nearby, but they find that substitution of employment is especially occurring between different subsidiaries in developing countries. In contrast, Bruno and Falzoni (2000) argue in a recent paper that once adjustment costs are taken into account strong substitution effects can be found, especially between parent firms and their affiliates in developed countries, while they find complementarity in the long run. Also, Blomström, Fors and Lipsey (1997) using 
firm level data, find that US multinationals have allocated some of their more labor intensive operations to affiliates in developing countries. They compare their results with those for Swedish multinationals and find no evidence in Swedish multinationals of labor substitution between home and foreign employment.

Likewise, Hatzius (1998) uses firm level data of Swedish multinational corporations to estimate constant output labor demand equations. He reports evidence showing positive substitution effects between parent and affiliate employment in estimating parent labor demand equations, however, no distinction is made between the locations of the subsidiaries. Braconier and Ekholm (1999) also use Swedish firm level panel data and find substitutability between parent employment in Sweden and affiliate employment in other high-income locations.

In contrast to these latter papers, which use relatively small (census type) data sets, this paper covers all medium and large sized parent MNEs in the EU with affilatiates either in the EU or in CEE or both. Furthermore, this paper makes a distinction between affiliates that are located in the EU versus those located in CEE. This allows us to test whether the opening up of CEE has contributed to job loss in the EU, an argument often used in the popular press.

\section{Theoretical and Econometric Framework}

Consider a MNE that produces global output, $y$, with three input factors, parent employment, $L_{p}$, daughter employment, $L_{d}$ and capital, $K$,

$$
y=F\left(L_{p}, L_{d}, K\right)
$$

where $F$ is the production function. We assume that $\mathrm{K}$ is perfectly mobile between different locations. In our empirical model we also will assume that employment in the subsidiaries can be distinguished between employment in EU subsidiaries and employment in CEE subsidiaries.

Total cost minimization under the constraint (1) yields us the conditional demand for parent employment 
where $\frac{\partial h_{p}}{\partial w_{p}}<0 ; \frac{\partial h_{p}}{\partial w_{d}}>0 ; \frac{\partial h_{p}}{\partial r}>0 ; \frac{\partial h_{p}}{\partial y}>0$

$w_{p}$ is the parent unit wage cost, $w_{d}$ is the subsidiary unit wage cost, $r$ is the unit cost of capital and $y$ is total output of the MNE.

An increase in the parent unit wage cost should lead to a decrease in the demand for parent employment, while an increase in the subsidiary unit wage cost should lead to an increase in the demand for parent employment, as long as $\frac{\partial h_{p}}{\partial w_{d}}>0$, which indicates that parent and subsidiary employment are substitutes. The larger this derivative, the stronger is the substitutability between parent and daughter employment and vice versa. In the extreme case where parent and daughter employment are perfect complements this derivative is equal to zero. This essentially is what we will be testing.

The theoretical literature on FDI location decisions distinguishes between 'horizontal' FDI and 'vertical' FDI (e.g. Markusen, 1995). The former type of FDI is more concerned with product market expansion, while the latter with exploiting cheaper costs of production. We would expect that labor substitution is more likely to take place when:

(i) The proximity to the final market matters to locate production, thus substitutability is more likely to occur between subsidiaries and the parent firm if they are located close to each other (e.g. Brainard, 1997).

(ii) If factor proportions are similar in the different locations. Since the distribution of skills and other factors differ across locations, the degree of substitution will differ.

These substitution effects can be estimated using the conditional demand for labor in (2). It gives an indication of the technological substitution possibilities between parent and subsidiary employment, given a certain output level. It represents the technological possibilities to move along the same isoquant. Of course if relative wages are changing then also the marginal costs of production are changing and therefore the optimal supply of output. Hence, the assumption of having a constant 
output in (2) may no longer be relevant. We can relax this assumption by deriving the labor demand functions for the MNE from profit maximization. This yields the unconditional or Marshallian demand functions for labor, where output is chosen optimally according to the supply function of the firm. This implies that the demand for parent employment is no longer a function of a given output level, but rather of the product market price or

$$
L_{p}=g_{p}\left(w_{p}, w_{d}, r, p\right)
$$

Again, the cross-price elasticities give an indication about how home employment is substituted for foreign employment, but now taking into account the effect of wages on output. Equations (2) and (3) will form the basis of our empirical specifications. In particular we will estimate (2) and (3) by assuming a log-linear approximation. Furthermore, we assume that the input factor, daughter employment, can be considered as two input factors, employment in EU subsidiaries and employment in CEE subsidiaries. For equation (2) this reduces to the following empirical specification for parent employment,

$$
\ln L_{j p}=\alpha_{j p}+\alpha_{1} \ln w_{j p}+\alpha_{2} \ln w_{j d e u}+\alpha_{3} \ln w_{j d c e e}+\alpha_{4} \ln y_{j}+\alpha_{5} \ln r+\varepsilon_{j p}
$$

where $j$ stands for firm $j, p$ for the parent and $d$ daughter company, $\alpha_{j p}$ is a firm specific fixed effect that is not observable. This may include distance between the parent and daughter company, in general it refers to unobserved heterogeneity, the subscripts $e u$ and cee refer to the European Union and Central and Eastern Europe respectively, $\alpha_{1,2,3,4,5}$ are parameters to be estimated and $\varepsilon$ is a white noise error term.

An empirical tractable equation for the unconditional demand function of labor (3) is a little more complicated since we need to find good proxies for product market characteristics affecting the price in (3). We use sector level output (proxied by sector level value added) as a proxy for general product market conditions that is prevalent in a particular sector. We also use sector level unit wages and the unemployment rates for each country in our data set. We include sector level wages since changes in sector wide wage costs should affect the product supply function of the sector and therefore equilibrium prices and finally we include unemployment rates 
because these reflect aggregate demand shocks 3 . So an empirical specification for the unconditional demand function for parent employment is the following

$\ln L_{j p}=\beta_{j p}+\beta_{1} \ln w_{j p}+\beta_{2} \ln w_{j d e u}+\beta_{3} \ln w_{j d c e e}+\beta_{4} \ln r+\beta_{5} \ln y_{\mathrm{sec}}+\beta_{6} \ln w_{\mathrm{sec}}+\beta_{7} \ln U_{\text {country }}+\varepsilon_{j p}$

where $\beta_{j p}$ is an unobserved firm specific effect for parent firm $j, \beta_{1,-} \beta_{7}$, are parameters to be estimated.

\section{Data and Preliminary Facts}

The data consists of all companies that have to report full company accounts to the national statistical offices for which at least one of the following criteria is satisfied: total turnover of at least 12 million USD, total assets of at least 12 million USD or total employment of at least 150. Our data covers both manufacturing and non-manufacturing sectors and covers all countries in the European Union plus Central and Eastern European countries. This is a commercial database collected by "Bureau Van Dijck" which is a quoted software and consulting company on the (Euronext) stock market and is sold under the name of 'Amadeus'. The reported data includes information on the ownership structure of firms, in particular, whether a company is a part of a group or a multinational company. It provides information on the identification of the parent company and all its subsidiaries. We matched all such parent companies with their subsidiaries, the data appendix describes the construction of the data set and the variable definitions. We only retained those MNEs that have at least a $50 \%$ interest in their subsidiaries, hence, our data set covers the subsidiaries for which the parent companies have effective control. The ownership information refers to the year 1998. However, if a MNE reports a subsidiary in 1998 we assume it was part of that MNE throughout the sample period that we observe $\mathrm{t}^{7}$.

Furthermore, we only retrieved the companies for which unconsolidated accounts were available for both the parent and its subsidiaries. For some countries, such as Greece and Finland, in the data set not all information that we needed was reported.

\footnotetext{
${ }^{3}$ We also experimented with using sector dummy variables interacted with year dummies as an alternaive to proxy for product market conditions. The results obtained were very similar.

${ }^{4}$ So, we are not able to trace changes in ownership over time. We believe this is not a very serious problem since the results we obtain would be stronger if we would be able to identify the exact date of control of a MNE in a given subsidiary. So, our results can be viewed as a lower bound.
} 
This is due to the local accounting legislation of reporting figures on value added and wage costs. Our eventual data set covers 1,272 parent companies located in the EU, with 3,164 subsidiaries located in the EU and 227 subsidiaries located in Central and Eastern Europe. The data covers the period 1994-98 and is in the form of unbalanced panel dat 5 . Tables 1 and 2 show the distribution of parent firms and subsidiaries across the various EU countries. It can be noted that Germany, France and Belgium have almost $60 \%$ of the parent firms in our sample. Subsidiaries are mainly located in France, Italy, Spain and the UK. Only $6 \%$ of the affiliates are located in Central and Eastern Europe in our sample.

Many parent companies have more than 1 subsidiary in different locations both in the EU and CEE, thus in equation (4) we should include all the wages of all the subsidiaries, however this would not be tractable. Therefore we consider two groups of locations for subsidiaries, those located in the EU and those in $\mathrm{CEE}^{\mathrm{G}}$. We take the average wage of all EU subsidiaries of a given parent firm to proxy wages of subsidiaries located in the EU and likewise for CEE subsidiaries. Some of the MNEs in our sample have affiliates located only in the EU, some only in CEE and some MNEs have affiliates in both regions. In our analysis we assume that locations are exogenously given. Our data set only gives information on existing locations of affiliates, but no information on when an operation was started in particular regions. This assumption allows us to estimate equations (4) and (5) for all parent firms together, where wages are set equal to zero if the parent firm has no affiliate in a particular region ${ }^{1}$. We also experimented with estimating separate equations for the MNEs with only EU affiliates and MNEs with only CEE affiliates, our results remained the same.

\footnotetext{
${ }^{5}$ This changing of firm numbers in the data set may be due to the criteria imposed by Bureau Van Dijck to be in the data set, observations on some variables may be missing due to differences in accounting procedures or due to takeovers and mergers. However, we are not able to identify these, but as suggested before, this should imply that our results are a mere lower bound.

${ }^{6} \mathrm{We}$ also experimented with splitting the EU into the 'low wage' EU countries (Spain, Portugal, Italy, the UK and Ireland) versus the 'high wage' EU countries, however, our results did not fundamentally change, so we proceeded with the EU versus CEE countries.

${ }^{7}$ This is equivalent to estimating the following equation for (4):$$
\ln L_{j p}=\alpha_{j p}+\alpha_{1} \ln w_{j p}+\alpha_{2} \ln w_{j d} X E U+\alpha_{3} \ln w_{j d} X C E E+\alpha_{4} \ln y_{j}+\alpha_{5} \ln r+\alpha_{6} E U+\alpha_{7} C E E+\varepsilon_{j p}
$$
where EU is equal to 1 if a MNE has an affiliate in the EU and zero else, CEE is equal to 1 if the MNE has an affiliate in Central and Eastern Europe and zero else. By estimating this equation with a standard mean deviations fixed effects approach or by first differencing, the coefficients $\alpha_{j p}, \alpha_{6}, \alpha_{7}$ drop out.
} 
Table 3 shows summary statistics on the main variables that we employ in our analysis. We proxy output by the total value added of the MNE using a weighted sum of the value added of its subsidiaries and the parent value added. The user cost of capital we proxy by taking the real risk free rate of return, which can also be interpreted as the opportunity cost of capital. As we can see from table 3, parent companies in our sample employ on average more than 2100 persons, while their subsidiaries employ less workers on average. Furthermore, the average employment of European subsidiaries is lower than the average employment of subsidiaries located in Central and Eastern Europe. This is not surprising since unit labor costs are much lower in the latter region. Again from table 3 we can see that the unit labor cost is on average 6 times lower than the equivalent in a European subsidiary. Furthermore, the size distribution of firms in Central and Eastern Europe is also more skewed in favor of large firms, a legacy of the communist period (Roland, 2000 p. 14). Although the labor cost in Central and Eastern Europe is much lower than in Europe, also the average labor productivity is much lower. The value added per worker is on average lower in subsidiaries compared to the value added per worker in the parent company. Furthermore the average value added per worker in EU subsidiaries is much higher than the average value added per worker in a CEE subsidiary.

A first indication whether employment substitution may take place can be obtained by computing the correlations between employment growth in parent firms and the employment growth in their affiliates. We therefore regressed parent employment growth on employment growth in the affiliates. Table 4 shows the results. The correlation between parent employment growth and subsidiary employment growth is negative and statistically significant, but only for affiliates located in the EU. For affiliates located in CEE the correlation coefficient is still negative, but not statistically significant. The negative sign suggests that as affiliate employment increases parent employment decreases or that a substitution effect may exist. In the following sections we will test this in a more structural way.

\section{Results}

Table 5 shows firm level fixed effects estimates for equation (4) the conditional demand for labor of MNEs. Column (1) gives the results for the overall sample, while columns (2) and (3) for manufacturing and non-manufacturing 
respectively. In column (1) the own labor demand elasticity (the effect of $W_{P}$ ) is estimated at -0.89 . The effect of unit wage costs in subsidiaries located in the EU $\left(W_{E U}\right)$, is estimated positive and statistically significant, however, the unit wage costs of subsidiaries located in CEE $\left(W_{C E E}\right)$, is estimated positive, but not statistically significant. In other words, a decrease in the unit wage cost of EU subsidiaries would lead to a decrease of parent employment. Thus, parent employment and EU subsidiary employment are substitutes. This suggests that relocation of employment in MNEs is taking place among high wage EU countries and not so much between high wage parent countries and low wage countries in CEE. Furthermore, this effect is even stronger if we limit the sample to manufacturing firms only, where the elasticity of parent employment with respect to the unit wage cost in its EU subsidiaries is estimated at 0.125 . Column (3) shows the results for the non-manufacturing sector. Interestingly, the coefficient of wages in EU subsidiaries is now negative and statistically significant, while that of wages in CEE subsidiaries is positive and significant. Thus for the non-manufacturing sector it seems that parent employment and subsidiary employment within the EU is complementary, while employment between the EU parent and its CEE subsidiaries are substitutes. We would not expect to find substitution effects in the non-manufacturing sector since traditionally it is believed that there are more non-tradables in non-manufacturing. We therefore experimented with defining the non-manufacturing sector more narrowly. In particular, more than $30 \%$ of the firms in the non-manufacturing sector are operating in the wholesale trade sector. We therefore ran the above regressions excluding the wholesale sector. We also excluded the construction sector because construction could be considered closer to manufacturing. In Columns (4) and (5) we report the results for the non-manufacturing sector excluding wholesale trade and construction, which we could call the service sector, and the results for the wholesale trade and construction sectors respectively. It is clear that the substitution effect of column (3) is mainly driven by the wholesale trade and construction sectors. Once we exclude them we find no substitution between parent employment and affiliate employment in CEE. Interestingly in the wholesale trade and construction sectors we find substitution effects between parent firms and their affiliates in CEE.

These results are confirmed in table 6 where we report the unconditional demand functions for labor in the parent firm. Parent wages have a strong negative effect on parent employment and unit wage costs in EU subsidiaries have a positive 
and statistically significant effect on parent employment. This effect is driven by the manufacturing sector. A decrease of $10 \%$ in the unit wage cost of EU subsidiaries is associated with a decrease of $2.3 \%$ in parent employment in the manufacturing sector. This effect is statistically not different from zero in the non-manufacturing sector. So, once we take the scale effect into account in the non-manufacturing sector, wages in EU subsidiaries do not matter for parent employment. However, wages in CEE have a significant and positive impact on parent employment in the non-manufacturing sector, while this is not statistically significant for the manufacturing sector. Again this result is driven by the wholesale trade and construction sectors as can be seen from columns (4) and (5).

The results suggest that MNEs in manufacturing when investing in EU countries are mainly driven by 'vertical' FDI. This is also what theory would suggest. Transport costs and trade barriers are low for subsidiaries located within the EU. Furthermore, the relative factor endowments are similar in the various EU countries: the skill composition of the work force and the equipment that manufacturing firms have access to is very similar within the EU. In constract, manufacturing in CEE is characterized by outdated equipment and low labor productivity (as can be seen from table 3). So, substantial deep restructuring was needed in most of the manufacturing firms (e.g. Roland,2000). Apart from these structural features, there are also a number of institutional obstacles in CEE: market liberalization in many of these countries was postponed, soft budget constraints persisted and trade barriers were raised shortly after the opening of CEE to the rest of the world. So, this suggests that there are many factors why 'vertical' FDI in CEE may be less likely to take place, but rather 'horizontal' FDI, aimed at obtaining first mover advantages and market access. This is also what was found by earlier work on FDI flows in CEE based on firm level surveys: Lankes and Venables (1996) and Abraham and Konings (1999) use firm level survey data and find that labor costs were not the most important factor to invest in CEE, rather strategic reasons related to market penetration and expansion were the main driving forces behind FDI in CEE.

The results for the non-manufacturing sector suggest that employment relocation within the EU is irrelevant, but rather relocation between parent employment and subsidiary employment in CEE is important. This result is driven by investments in the wholesale trade and construction sectors. This makes sense if these investments are especially distribution activities, where cheaper labor costs may be a 
driving force to locate a distribution center in a low wage country. In these sectors the factor endowments are arguably not so different than those in the EU. In distribution activities no heavy equipment is used and the type of workers needed does not require special skills. For the service sector we find no substitution effects taking place between EU parents and their CEE affiliates. Given the non-tradable character of services this is what we would expect.

\section{Robustness checks}

In this section we look at the robustness of our results. One of the empirical regularities characterizing MNEs is that they mostly operate in sectors which are R\&D intensive and that MNEs often are characterized by high levels of intangible assets, which is often reflected in the skill composition of their workforce (Markusen,1995). The data that we use have no information on the skill composition of the workforce, so we treated labor as homogeneous. Slaughter (2000) has shown for the US, that this may not be too much of a problem. He finds that MNE transfer to low wage countries has occurred, however, he finds no evidence that this has contributed to shifts in the relative demand for fewer unskilled workers in the US. One way to test whether the skill-composition of the firm may matter in our analysis is to include a proxy for skills. We include as a proxy the intangible assets as a percentage of total assets in the parent firm. The higher this ratio the more likely firms have a skill intensive labor force. Since we do not have this information for all of our firms in the sample we loose a substantial number of observations. Nevertheless it is an interesting robustness check and tables A1 and A2 of appendix 2 show the results for the conditional and unconditional demand for labor. We can see that our main results are not affected in both the conditional and the unconditional demand for labor functions. In fact, we find that skill intensity has a positive effect on the demand for labor in parent companies, while the estimated elasticities are not much affected. We can also note that skill intensity only seems to matter for manufacturing firms and not so much for non-manufacturing firms. The skill differences for the latter group of firms are presumably less outspoken compared to manufacturing.

A second concern with the approach that we adopted is the potential endogeneity of wages and output. Furthermore the labor demand equations we estimated so far are static labor demand equations, however, it may be the case that 
there exists some dynamics in employment adjustment, e.g. due to adjustment costs. To check whether endogeneity mattered and whether hidden dynamics is present in our data we estimated both static and dynamic employment models where we treated the own wage and output as endogenous explanatory variables. We employ the simplest possible dynamic specification, by including a lagged dependent variable in our estimations. Furthermore, since the unobserved fixed effect is potentially correlated with the other explanatory variables we estimated the model in first differences to eliminates the fixed effect. This is essentially the procedure proposed by Arellano and Bond (1991) for estimating dynamic panel data models with endogenous explanatory variables.

By including a lagged dependent variable and because we estimate the model in first differences we introduce an endogeneity in the lagged dependent variable. So, we also instrumented the lagged dependent variable using the moment restrictions proposed by Arellano and Bond (1991). In particular, the advantage of using this method over other commonly used panel data estimation techniques lies in its efficient use of the number of instruments generated for the endogenous explanatory variables. For instance, in a first difference model valid instruments for the lagged dependent variable in 1998 are the level of the dependent variable in 1996, 1995, 1994, etc. since the lagged levels are not correlated with the differenced error term in 1998. In order to test the validity of these instruments a Sargan test of over identifying restrictions is computed and is asymptotically $\chi^{2}$ distributed. Because the model is estimated in first differences the equation will be characterized by the presence of first order serial correlation. However, what matters in a first difference model is the absence of second order serial correlation if the error term in the levels equation is white noise. Hence, we report a test for second order serial correlation which is asymptotitically $\mathrm{N}(0,1)$ distributed. Since the model is estimated in first differences and since lagged values (dated at least $t-2$ and before) of the endogenous variables are used, we need to observe firms for at least 3 consecutive time periods. This implies that we loose some firms in our analysis.

The number of parent firm level observations that we have available in each year is shown in table 7. Tables 8 and 9 show the results for the overall sample, while table 10 shows the results for the manufacturing sector only. The first column of tables 8 and 9 show the static model, while in the second column we allow for some 
dynamics in the employment equation. Our earlier results for both the conditional (table 8) and the unconditional (table 9) labor demand functions still hold. An increase in the own wage of the parent firm is associated with a decrease in parent employment. Furthermore, a decrease in the wage cost of the subsidiary located in the EU leads to a decrease in the demand for labor of the parent firm. Thus the result that parent employment and employment in EU subsidiaries are substitutes persist, both in the conditional demand and the unconditional demand for labor. The diagnostic tests in the first column also suggest that the instruments that were chosen for the potentially endogenous explanatory variables, the own wage and output, are valid (Sargan test). Moreover, the second order serial correlation test suggests that there is no serial correlation in the levels equation, which suggest that we do not miss any hidden dynamics. Nevertheless, in column (2) we include a lagged dependent variable to test potential adjustment lags in employment. We find a statistically significant effect of the lagged dependent variable in both the conditional and unconditional demand functions. Furthermore, our main results persist: the own wage effect has a negative impact on employment in the parent firm, the wage cost of the EU subsidiaries has a positive effect on parent employment, confirming the substitutability between parent employment and employment in EU subsidiaries. In table 9, estimating the unconditional demand function, we also find a weak positive effect of wage costs in the CEE subsidiaries, once we allow for adjustment lags in employment.

Table 10 shows the IV results for the manufacturing sector and table 11 for the non-manufacturing sector. The results we obtained earlier are robust to allowing for the possibility of endogeneity and employment lags. Furthermore, we find for the manufacturing sector that in addition to the substitutability between home employment and EU subsidiary employment, also there is, albeit weaker, substitutability between home employment and CEE subsidiary employment. Our earlier results that for the non-manufacturing sector there is no effect of EU subsidiary wages on parent employment and a positive effect of CEE subsidiary wages on parent employment is also confirmed. Again, wholesale trade and construction drive the latter effect. 


\section{Conclusions}

This paper used a large representative panel data set of more than 1,200 EU MNEs and their affiliates located in the EU and CEE to test whether parent jobs are substituted for by foreign ones. We estimated both conditional and unconditional demand functions for parent employment. We find evidence supporting the presence of substitution effects between parent employment and foreign employment, but the effect depends on the sector, manufacturing or non-manufacturing, in which they operate.

For manufacturing firms, we find evidence that EU firms substitute parent jobs for foreign ones. This effect is only significant for affiliates located within the EU. We find no strong evidence that employment substitution takes place between EU parents and CEE subsidiaries. This gives support to the proximity hypothesis discussed in the literature. For the non-manufacturing sector, in particular the wholesale trade and construction sectors, we find that parent employment and CEE employment are substitutes. For firms operating in the service sectors we find no substitution effects.

The results in this paper suggest that on average the opening of CEE should not be viewed as a threat to European employment. It is rather competition between EU countries that lead multinational parent firms to relocate employment between EU locations. 
Table 1: Distribution of Parent Firms across the EU in the sample

\begin{tabular}{|l|l|}
\hline Parent Country & Frequency of Firms \\
\hline Austria & $1.77 \%$ \\
\hline Belgium & $10.34 \%$ \\
\hline Denmark & $5.25 \%$ \\
\hline Ireland & $0.13 \%$ \\
\hline Finland & $3.65 \%$ \\
\hline France & $17.74 \%$ \\
\hline Germany & $29.94 \%$ \\
\hline Greece & $0.56 \%$ \\
\hline Italy & $9.98 \%$ \\
\hline Luxemburg & $0.33 \%$ \\
\hline Netherlands & $4.09 \%$ \\
\hline Portugal & $0.11 \%$ \\
\hline Spain & $3.37 \%$ \\
\hline Sweden & $3.62 \%$ \\
\hline UK & $8.12 \%$ \\
\hline
\end{tabular}

Table 2:Distribution of Subsidiaries across countries

\begin{tabular}{|l|l|}
\hline Affiliate Country & Frequency of Firms \\
\hline Central and Eastern Europe & $6.34 \%$ \\
\hline Austria & $1.39 \%$ \\
\hline Belgium & $9.29 \%$ \\
\hline Denmark & $1.65 \%$ \\
\hline France & $19.34 \%$ \\
\hline Germany & $3.03 \%$ \\
\hline Netherlands & $2.67 \%$ \\
\hline Ireland & $1.01 \%$ \\
\hline Italy & $11.34 \%$ \\
\hline Luxemburg & $0.74 \%$ \\
\hline Portugal & $1.89 \%$ \\
\hline Spain & $18.71 \%$ \\
\hline Sweden & $2.77 \%$ \\
\hline UK & $19.83 \%$ \\
\hline
\end{tabular}


Table 3: Summary Statistics

\begin{tabular}{|l|c|c|c|}
\hline & Overall Sample & Manufacturing & Non-Manufacturing \\
\hline Parent employment & 2174 & 2452 & 1619 \\
\hline $\begin{array}{l}\text { Daughter employment } \\
\text { (EU) }\end{array}$ & 328 & 300 & 689 \\
\hline $\begin{array}{l}\text { Daughter employment } \\
\text { (CEE) }\end{array}$ & 669 & 674 & 55.86 \\
\hline Parent unit wage cost & 52.11 & 45.49 & 44.10 \\
\hline $\begin{array}{l}\text { Daughter unit wage } \\
\text { cost (EU) }\end{array}$ & 44.97 & 7.85 & 9.49 \\
\hline $\begin{array}{l}\text { Daughter unit wage } \\
\text { cost (CEE) }\end{array}$ & 8.48 & 148.09 & 349.23 \\
\hline $\begin{array}{l}\text { Parent value added per } \\
\text { worker }\end{array}$ & 213.29 & 161.69 & 105.42 \\
\hline $\begin{array}{l}\text { Daughter value added } \\
\text { per worker (EU) }\end{array}$ & 142.17 & 23.81 & 4.60 \\
\hline $\begin{array}{l}\text { Daughter value added } \\
\text { per worker (CEE) }\end{array}$ & 21.43 & $4.5 \%$ & $33.3 \%$ \\
\hline $\begin{array}{l}\text { Opportunity cost of } \\
\text { capital }\end{array}$ & $4.5 \%$ & $66.7 \%$ & \\
\hline Distribution of Firms & $100 \%$ & & \\
\hline
\end{tabular}

Notes: (1) Source: Amadeus (June, 2000)

(2) US\$1,000.00 except employment

Table 4: Correlations between employment growth in parent firms and their affiliates

\begin{tabular}{|l|l|l|l|}
\hline & Whole sample & Manufacturing & Non-manufacturing \\
\hline Growth rate in EU affiliate & $-0.0343^{* * *}$ & $-0.0486^{* * *}$ & -0.019 \\
employment & $(0.016)$ & $(0.022)$ & $(0.023)$ \\
\hline Growth rate in CEE affiliate & -0.0444 & -0.018 & -0.196 \\
employment & $(0.103)$ & $(0.020)$ & $(0.268)$ \\
\hline
\end{tabular}

Note: (i) These correlations are computed on the basis of a regression of parent employment growth on subsidiary employment growth, including year dummies. (ii) standard errors in brackets 
Table 5: Conditional Demand for Parent Employment

(Fixed Effects Estimators)

\begin{tabular}{|c|c|c|c|c|c|}
\hline & $\begin{array}{c}\text { (1) } \\
\text { whole sample }\end{array}$ & $\begin{array}{c}(2) \\
\text { manufacturing }\end{array}$ & $\begin{array}{c}\text { (3) } \\
\text { non- } \\
\text { manufacturing }\end{array}$ & $\begin{array}{c}(4) \\
\text { services }\end{array}$ & $\begin{array}{c}(5) \\
\text { wholesale and } \\
\text { construction }\end{array}$ \\
\hline $\mathrm{W}_{\mathrm{p}}$ & $\begin{array}{c}-0.895 * * * \\
(0.033)\end{array}$ & $\begin{array}{c}-0.999 * * * \\
(0.041)\end{array}$ & $\begin{array}{c}-0.743 * * * \\
(0.054)\end{array}$ & $\begin{array}{c}-0.707 * * * \\
(0.086)\end{array}$ & $\begin{array}{c}-0.761 * * * \\
(0.06)\end{array}$ \\
\hline $\mathrm{W}_{\mathrm{EU}}$ & $\begin{array}{c}0.073 * * * \\
(0.021)\end{array}$ & $\begin{array}{c}0.125 * * * \\
(0.023)\end{array}$ & $\begin{array}{c}-0.081 * * \\
(0.041)\end{array}$ & $\begin{array}{c}-0.104 * * \\
(0.049)\end{array}$ & $\begin{array}{l}-0.022 \\
(0.078)\end{array}$ \\
\hline $\mathrm{W}_{\mathrm{CEE}}$ & $\begin{array}{c}0.015 \\
(0.022)\end{array}$ & $\begin{array}{l}-0.013 \\
(0.024)\end{array}$ & $\begin{array}{c}0.103 * * \\
(0.048)\end{array}$ & $\begin{array}{c}0.032 \\
(0.084)\end{array}$ & $\begin{array}{c}0.132 * * \\
(0.055)\end{array}$ \\
\hline$Y$ & $\begin{array}{c}0.492 * * * \\
(0.016)\end{array}$ & $\begin{array}{c}0.576^{* * * *} \\
(0.020)\end{array}$ & $\begin{array}{c}0.357 * * * \\
(0.027)\end{array}$ & $\begin{array}{c}0.439 * * * \\
(0.035)\end{array}$ & $\begin{array}{c}0.207 * * * \\
(0.043)\end{array}$ \\
\hline $\mathrm{R}$ & $\begin{array}{l}-0.018 \\
(0.046)\end{array}$ & $\begin{array}{l}-0.008 \\
(0.052)\end{array}$ & $\begin{array}{l}-0.109 \\
(0.093)\end{array}$ & $\begin{array}{l}-0.013 \\
(0.119)\end{array}$ & $\begin{array}{c}-0.305 * * \\
(0.146)\end{array}$ \\
\hline $\begin{array}{c}\text { No. of } \\
\text { observations }\end{array}$ & 3964 & 2650 & 1314 & 848 & 466 \\
\hline
\end{tabular}

Notes: (i) All equations include year dummies

(ii) $* * *$ indicates $1 \%$ significance level, $* * 5 \%$ significance and $* 10 \%$ significance

(iii) Robust standard errors in brackets. 
Table 6: Unconditional Demand for Parent Employment

\begin{tabular}{|c|c|c|c|c|c|}
\hline & $\begin{array}{c}\text { (1) } \\
\text { whole sample }\end{array}$ & $\begin{array}{c}(2) \\
\text { manufacturing }\end{array}$ & $\begin{array}{c}\text { (3) } \\
\text { non-manufacturing }\end{array}$ & $\begin{array}{c}(4) \\
\text { services }\end{array}$ & $\begin{array}{c}(5) \\
\text { wholesale and } \\
\text { construction }\end{array}$ \\
\hline $\mathrm{W}_{\mathrm{p}}$ & $\begin{array}{c}-0.773 * * * \\
(0.041)\end{array}$ & $\begin{array}{c}-0.842 * * * \\
(0.053)\end{array}$ & $\begin{array}{c}-0.694 * * * \\
(0.063)\end{array}$ & $\begin{array}{c}-0.578 * * * \\
(0.102)\end{array}$ & $\begin{array}{c}-0.785^{* * *} * \\
(0.076)\end{array}$ \\
\hline $\mathrm{W}_{\mathrm{EU}}$ & $\begin{array}{c}0.148 * * * \\
(0.026)\end{array}$ & $\begin{array}{c}0.227 * * * \\
(0.031)\end{array}$ & $\begin{array}{l}-0.043 \\
(0.050)\end{array}$ & $\begin{array}{l}-0.074 \\
(0.061)\end{array}$ & $\begin{array}{c}0.031 \\
(0.092)\end{array}$ \\
\hline $\mathrm{W}_{\mathrm{CEE}}$ & $\begin{array}{c}0.033 \\
(0.028)\end{array}$ & $\begin{array}{c}0.007 \\
(0.032)\end{array}$ & $\begin{array}{l}0.116 * * \\
(0.058)\end{array}$ & $\begin{array}{c}0.079 \\
(0.101)\end{array}$ & $\begin{array}{l}0.14 * * \\
(0.065)\end{array}$ \\
\hline $\begin{array}{c}\mathrm{R} \\
\text { (industry product } \\
\text { mkt. Controls) }\end{array}$ & $\begin{array}{l}0.140 * * \\
(0.060)\end{array}$ & $\begin{array}{l}0.131 * * \\
(0.070)\end{array}$ & $\begin{array}{c}0.125 \\
(0.112)\end{array}$ & $\begin{array}{c}0.126 \\
(0.148)\end{array}$ & $\begin{array}{c}0.118 \\
(0.173)\end{array}$ \\
\hline $\begin{array}{l}\text { Ysec } \\
\text { Wsec }\end{array}$ & $\begin{array}{c}0.221 * * \\
(0.073) \\
0.010 \\
(0.101)\end{array}$ & $\begin{array}{c}0.205 * * \\
(0.106) \\
-0.044 \\
(0.139)\end{array}$ & $\begin{array}{c}0.127 \\
(0.115) \\
0.148 \\
(0.163)\end{array}$ & $\begin{array}{c}0.118 \\
(0.146) \\
0.259 \\
(0.254)\end{array}$ & $\begin{array}{c}-0.008 \\
(2.603) \\
-0.067 \\
(0.658)\end{array}$ \\
\hline $\mathrm{U}_{\text {country }}$ & $\begin{array}{c}0.039 \\
(0.111)\end{array}$ & $\begin{array}{c}0.138 \\
(0.131)\end{array}$ & $\begin{array}{l}-0.208 \\
(0.208)\end{array}$ & $\begin{array}{c}0.006 \\
(0.296)\end{array}$ & $\begin{array}{l}-0.411 \\
(0.285)\end{array}$ \\
\hline No. of observations & 4222 & 2784 & 1438 & 935 & 503 \\
\hline
\end{tabular}

Notes: (i) All equations include year dummies

(ii) $* * *$ indicates $1 \%$ significance level, $* * 5 \%$ significance and $* 10 \%$ significance

(iii) Robust standard errors in brackets. 
Table 7: Structure of the panel for IV estimates

\begin{tabular}{|l|l|}
\hline Number of consecutive years & Number of firms \\
\hline 3 & 232 \\
\hline 4 & 302 \\
\hline 5 & 271 \\
\hline Total number of firms & 805 \\
\hline
\end{tabular}

Table 8: Conditional Demand for Parent Employment: IV Estimates using GMM (first differences)

\begin{tabular}{|c|c|c|}
\hline & $(1)$ & $(2)$ \\
$\Delta L_{p \mathrm{jt}-1}$ & - & $0.285^{* *}$ \\
$\Delta W_{p \mathrm{jt}}$ & $-1.116^{* *}$ & $(0.160)$ \\
$\Delta W_{E U \mathrm{jt}}$ & $(0.394)$ & $-0.69^{* *}$ \\
$\Delta W_{C E E \mathrm{jt}}$ & $0.138^{* *}$ & $(0.34)$ \\
$\Delta R_{\mathrm{jt}}$ & $(0.060)$ & $0.148^{* *}$ \\
$\Delta Y_{\mathrm{jt}}$ & -0.033 & $(0.058)$ \\
$\Delta Y_{\mathrm{sec}}$ & $(0.026)$ & -0.026 \\
$\Delta W_{\text {sec }}$ & 0.053 & $(0.022)$ \\
$\Delta U_{\text {country }}$ & $0.103)$ & 0.035 \\
Sargan Test & $(0.245)$ & $0.087)$ \\
Second OSC Test & - & $0.845^{* * *}$ \\
& - & $-0.180)$ \\
\hline
\end{tabular}

Notes: (i) All Equations include year dummies; (ii) $* * * 1 \%$ significance level, ** \& * significant at $5 \%$ and $10 \%$ confidence level, (iii) Lagged employment, parent wages and firm level output are instrumented using all available moment restrictions from $t-2$ back. 
Table 9: Unconditional Demand for Parent Employment: IV Estimates using GMM (first differences)

\begin{tabular}{|c|c|c|}
\hline & $(1)$ & $(2)$ \\
$\Delta L_{p \mathrm{jt}-1}$ & - & $0.276^{* *}$ \\
$\Delta W_{\mathrm{pjt}}$ & $-0.747^{* * *}$ & $(0.165)$ \\
$\Delta W_{\text {Eujt }}$ & $(0.255)$ & $-0.667^{* * *}$ \\
$\Delta W_{C E E \mathrm{jt}}$ & $0.190^{* *}$ & $(0.253)$ \\
$\Delta R_{\mathrm{jt}}$ & $(0.10)$ & $0.181^{* *}$ \\
$\Delta Y_{\mathrm{jt}}$ & $-0.018^{*}$ & $(0.10)$ \\
$\Delta Y_{\text {sec }}$ & $(0.010)$ & $0.023^{* *}$ \\
$\Delta W_{\text {sec }}$ & 0.067 & $(0.010))$ \\
$\Delta U_{\text {country }}$ & $(0.084)$ & 0.111 \\
Sargan Test & - & $(0.087)$ \\
Second OSC Test & $0.161^{* *}$ & - \\
\end{tabular}

Notes: (i) All Equations include year dummies; (ii) $* * * 1 \%$ significance level, ** \& * significant at 5\% and $10 \%$ confidence level. (iii) Lagged employment is instrumented with all available moment restrictions from $t-3$ back and parent wage is instrumented with all available moment restrictions from $t-2$ back. 
Table 10: Conditional and Unconditional Demand for Parent Employment: manufacturing sector only IV Estimates using GMM (first differences)

\begin{tabular}{|c|c|c|c|c|}
\hline & \multicolumn{2}{|c|}{ Conditional Demand } & \multicolumn{2}{|c|}{ Unconditional Demand } \\
\hline & (1) & $(2)$ & (3) & (4) \\
\hline$\Delta L_{\mathrm{pjt}-1}$ & - & $\begin{array}{c}0.447 * * \\
(0.158)\end{array}$ & - & $\begin{array}{c}0.450 * * \\
(0.177)\end{array}$ \\
\hline$\Delta \mathrm{W}_{\mathrm{pjt}}$ & $\begin{array}{c}-0.968 * * * \\
(0.256)\end{array}$ & $\begin{array}{c}-0.506^{* *} \\
(0.2)\end{array}$ & $\begin{array}{c}-0.986 * * \\
(0.325)\end{array}$ & $\begin{array}{c}-1.137 * * \\
(0.441)\end{array}$ \\
\hline$\Lambda \mathrm{W}_{\mathrm{FUi}}$ & $0.176 * * *$ & $0.263 * * *$ & $0.240 * *$ & $0.298 * * *$ \\
\hline$\Delta v$ EUjt & $(0.049)$ & $(0.046)$ & $(0.093)$ & $(0.066)$ \\
\hline$\Delta W_{\text {CFFit }}$ & -0.025 & -0.006 & $0.012 *$ & $0.022 * *$ \\
\hline$\Delta v_{\text {CEEjt }}$ & $(0.023)$ & $(0.018)$ & $(0.008)$ & $(0.010)$ \\
\hline$\Delta R_{\mathrm{it}}$ & 0.088 & 0.109 & $0.199 * *$ & $0.326 * *$ \\
\hline$\Delta \boldsymbol{N}_{\mathrm{jt}}$ & $(0.081)$ & $(0.090)$ & $(0.083)$ & $(0.106)$ \\
\hline$\Delta Y_{\mathrm{jt}}$ & $\begin{array}{c}0.611 * * * \\
(0.248)\end{array}$ & $\begin{array}{c}0.529 * * * \\
(0.201)\end{array}$ & & - \\
\hline$\Delta Y_{\mathrm{sec}}$ & - & - & $\begin{array}{c}0.120 \\
(0.097)\end{array}$ & $\begin{array}{c}0.395 * * \\
(0.127)\end{array}$ \\
\hline$\Delta W_{\mathrm{sec}}$ & - & - & $\begin{array}{l}-0.014 \\
(0.093)\end{array}$ & $\begin{array}{c}-0.021 \\
(0.100)\end{array}$ \\
\hline$\Delta U_{\text {country }}$ & - & - & $-0.382 *$ & $\begin{array}{l}-0.115 \\
(0258)\end{array}$ \\
\hline Sargan Test & $9.01(\mathrm{df}=10)$ & $14.4(\mathrm{df}=12)$ & $3.72(\mathrm{df}=5)$ & $11.7(\mathrm{df}=7)$ \\
\hline Second OSC Test & 0.454 & -0.920 & 1.304 & 1.197 \\
\hline
\end{tabular}

Notes: (i) All equations include year dummies; (ii)*** $1 \%$ significance level, $* * \& *$ significant at $5 \%$ and $10 \%$ confidence level, (iii) Lagged employment, parent wages and firm level output are instrumented using all available moment restrictions from $t-2$ back. 


\section{Table 11: Conditional and Unconditional Parent Employment: non-manufacturing sector only IV Estimates using GMM (first differences)}

\begin{tabular}{|c|c|c|c|c|}
\hline & \multicolumn{2}{|c|}{ Conditional Demand } & \multicolumn{2}{|c|}{ Unconditional Demand } \\
\hline & (1) & (2) & (3) & (4) \\
\hline$\Delta L_{\mathrm{Dit} 1}$ & - & 0.221 & - & 0.219 \\
\hline & & $(0.199)$ & & $(0.192)$ \\
\hline$\Lambda W_{\mathrm{Dit}}$ & $-0.472 *$ & $-0.431 *$ & $-0.647 * *$ & $-0.562 * *$ \\
\hline$\Delta W W_{\mathrm{Pjt}}$ & $(0.289)$ & $(0.285)$ & $(0.292)$ & $(0.289)$ \\
\hline$\Lambda \mathbf{W}_{\Gamma_{1}}$ & -0.018 & -0.014 & -0.018 & -0.014 \\
\hline$\Delta v_{\text {Eujt }}$ & $(0.037)$ & $(0.037)$ & $(0.035)$ & $(0.034)$ \\
\hline$\Delta W_{\text {CEEit }}$ & 0.023 & 0.025 & $0.053 * *$ & $0.049 * *$ \\
\hline$\Delta v$ CEEjt & $(0.019)$ & $(0.018)$ & $(0.021)$ & $(0.020)$ \\
\hline$\Lambda R$ & 0.013 & 0.052 & 0.073 & 0.113 \\
\hline$\Delta \nabla_{\mathrm{jt}}$ & $(0.081)$ & $(0.10)$ & $(0.079)$ & $(0.093)$ \\
\hline$\Delta Y_{\mathrm{jt}}$ & $\begin{array}{c}0.191 * * * \\
(0.058)\end{array}$ & $\begin{array}{c}0.174 * * \\
(0.063)\end{array}$ & - & - \\
\hline$\Delta Y_{\mathrm{sec}}$ & - & - & 0.017 & 0.021 \\
\hline UW & - & - & $\begin{array}{c}(0.148) \\
0.205\end{array}$ & $\begin{array}{c}(0.146) \\
0.241\end{array}$ \\
\hline$\Delta W_{\mathrm{sec}}$ & - & - & $(0.167)$ & $(0.173)$ \\
\hline$\Delta U_{\text {country }}$ & - & - & $\begin{array}{c}-0.679 * * * \\
(0.206)\end{array}$ & $\begin{array}{c}-0.591 * * \\
(0.205)\end{array}$ \\
\hline Sargan Test & $8.26(\mathrm{df}=11)$ & $8.44(\mathrm{df}=10)$ & $7.48(\mathrm{df}=11)$ & $6.76(\mathrm{df}=10)$ \\
\hline Second OSC Test & 0.534 & 1.263 & 0.855 & 1.311 \\
\hline
\end{tabular}

Notes: (i) All equations include year dummies; (ii)*** $1 \%$ significance level, $* * \& *$ significant at $5 \%$ and $10 \%$ confidence level, (iii) Instruments for parent wages and lagged employment include all available moment restrictions from on employment and parent wages from $t$ - 2 back. 


\section{The Database}

\section{APPENDIX 1}

To construct the database linking EU parent firms with foreign daughters located in the EU and CEE, it required a unique identifier. Amadeus contains the National ID number of all firms and therefore, it is possible to link firms from a multinational group. This is possible because Parent firms report having an ownership stake in a foreign daughter identifying the daughter by national ID number. The daughter firm reports the ownership structure of the firm giving the national identification ID of the parent(s) and owner. Thus, we employed these unique ID numbers to match a parent with all its foreign daughters.

We only kept those subsidiaries for which the parent company had an ownership share of at least 50\%. This ownership information, however, was only available for the year 1998. So we assume that the ownership structure of the MNE is the same throughout the sample period.

\section{Definition of the Variables}

Since some MNEs have more than one subsidiary we constructed the average values of the variables of interest taken over all subsidiaries in Europe and the average values of the variables of interest taken over all subsidiaries in Central and Eastern Europe.

Total output of the MNE $(Y)$ : the weighted sum of value added in the parent company and the value added of its subsidiaries, where the weight represent the importance of value added in total value added for the parent versus the subsidiaries.

Unit wage cost of the parent $(W p)$ : total wage bill of the parent company divided by total employment of the parent company.

Unit wage cost of the subsidiaries in the EU (Wseu): the average total wage bill of all EU subsidiaries of that particular MNE divided by the average total employment of all EU subsidiaries of that particular MNE.

Unit wage cost of the subsidiaries in CEE (Wscee): the average total wage bill of all CEE subsidiaries of that particular MNE divided by the average total employment of all CEE subsidiaries of that particular MNE.

Unit cost of capital $(R)$ : the real risk free rate of return in each parent country, computed as the 10 year government bond yield minus the inflation rate in each country.

Sector output (Ysec): the total value added in each 2-digit NACE sector in the EU, source: computed from Amadeus.

Sector unit wage cost (Wsec): the total wage bill divided by the total employment in each 2-digit NACE sector in the EU, source: computed from Amadeus.

Unemployment rate $(U)$ : the country specific unemployment rate using the harmonized OECD definition, source: OECD. 
Appendix 2: Some Further Experiments: Controlling for Skills

Table A1: Conditional Demand for Labour, controlling for skills

\begin{tabular}{|c|c|c|c|}
\hline & $\begin{array}{c}(1) \\
\text { whole } \\
\text { sample }\end{array}$ & $\begin{array}{c}(2) \\
\text { manufacturing }\end{array}$ & $\begin{array}{c}(3) \\
\text { non- } \\
\text { manufacturing }\end{array}$ \\
\hline \multirow{2}{*}{$\mathrm{W}_{\mathrm{P}}$} & $\begin{array}{c}-0.923 * * * \\
(0.040)\end{array}$ & $\begin{array}{c}-1.08 * * * \\
(0.052)\end{array}$ & $\begin{array}{c}-0.712 * * * \\
(0.062)\end{array}$ \\
$\mathrm{W}_{\mathrm{EU}}$ & $0.077 * * *$ & $0.139 * * *$ & $-0.092^{* *}$ \\
& $(0.024)$ & $(0.028)$ & $(0.045)$ \\
$\mathrm{W}_{\mathrm{CEE}}$ & 0.019 & -0.035 & $0.18 * *$ \\
& $(0.034)$ & $(0.037)$ & $(0.074)$ \\
$\mathrm{Y}$ & $0.484 * * *$ & $0.558 * * *$ & $0.367 * * *$ \\
& $(0.019)$ & $(0.025)$ & $(0.030)$ \\
$\mathrm{R}$ & 0.015 & 0.008 & -0.101 \\
& $(0.057)$ & $(0.067)$ & $(0.10)$ \\
Skill intensity & $0.915 * *$ & $0.845^{* *}$ & 0.497 \\
No. of & $(0.331)$ & $(0.378)$ & $(0.651)$ \\
observations & 3039 & 1955 & 1314 \\
\hline
\end{tabular}

Notes: (i) All equations include year dummies; (ii) $* * *$ indicates $1 \%$ significance level, $* * 5 \%$ significance and $* 10 \%$ significance, (iii) Robust standard errors in brackets. 
Table A2: Unconditional Demand for Labour, controlling for skills

\begin{tabular}{|c|c|c|c|}
\hline & $\begin{array}{c}\text { (1) } \\
\text { whole sample }\end{array}$ & $\begin{array}{c}(2) \\
\text { manufacturing }\end{array}$ & $\begin{array}{c}\text { (3) } \\
\text { non- } \\
\text { manufacturing }\end{array}$ \\
\hline $\mathrm{W}_{\mathrm{P}}$ & $\begin{array}{c}-0.760 * * * \\
(0.049)\end{array}$ & $\begin{array}{c}-0.872 * * * \\
(0.066)\end{array}$ & $\begin{array}{c}-0.629 * * * \\
(0.073)\end{array}$ \\
\hline $\mathrm{W}_{\mathrm{EU}}$ & $\begin{array}{c}0.156 * * * \\
(0.030)\end{array}$ & $\begin{array}{c}0.247 * * * \\
(0.036)\end{array}$ & $\begin{array}{c}-0.058 \\
(0.054)\end{array}$ \\
\hline $\mathrm{W}_{\mathrm{CEE}}$ & $\begin{array}{c}0.040 \\
(0.043)\end{array}$ & $\begin{array}{l}0.006 \\
(0.05)\end{array}$ & $\begin{array}{c}0.144^{*} \\
(0.08)\end{array}$ \\
\hline $\mathrm{R}$ & $\begin{array}{c}0.179 * * \\
(0.073)\end{array}$ & $\begin{array}{c}0.163 * * \\
(0.089)\end{array}$ & $\begin{array}{c}0.126 \\
(0.130)\end{array}$ \\
\hline Skill intensity & $\begin{array}{c}1.638 * * * \\
(0.403)\end{array}$ & $\begin{array}{c}2.205^{* * * *} \\
(0.483)\end{array}$ & $\begin{array}{c}0.050 \\
(0.072)\end{array}$ \\
\hline $\begin{array}{l}\text { Ysec } \\
\text { Wsec }\end{array}$ & $\begin{array}{c}0.174 * * \\
(0.08) \\
0.032 \\
(0.128)\end{array}$ & $\begin{array}{c}0.161 \\
(0.136) \\
0.060 \\
(0.179)\end{array}$ & $\begin{array}{c}0.097 \\
(0.13) \\
0.038 \\
(0.154)\end{array}$ \\
\hline $\mathrm{U}$ & $\begin{array}{c}0.432 * * \\
(0.152)\end{array}$ & $\begin{array}{c}0.579 * * \\
(0.184)\end{array}$ & $\begin{array}{c}0.011 \\
(0.268)\end{array}$ \\
\hline No. of observations & 3221 & 2030 & 1197 \\
\hline
\end{tabular}

Notes: (i) All equations include year dummies; (ii) $* * *$ indicates $1 \%$ significance level, ** 5\% significance and $* 10 \%$ significance, (iii) Robust standard errors in brackets. 
Figure 1: Foreign Direct investment Outflows

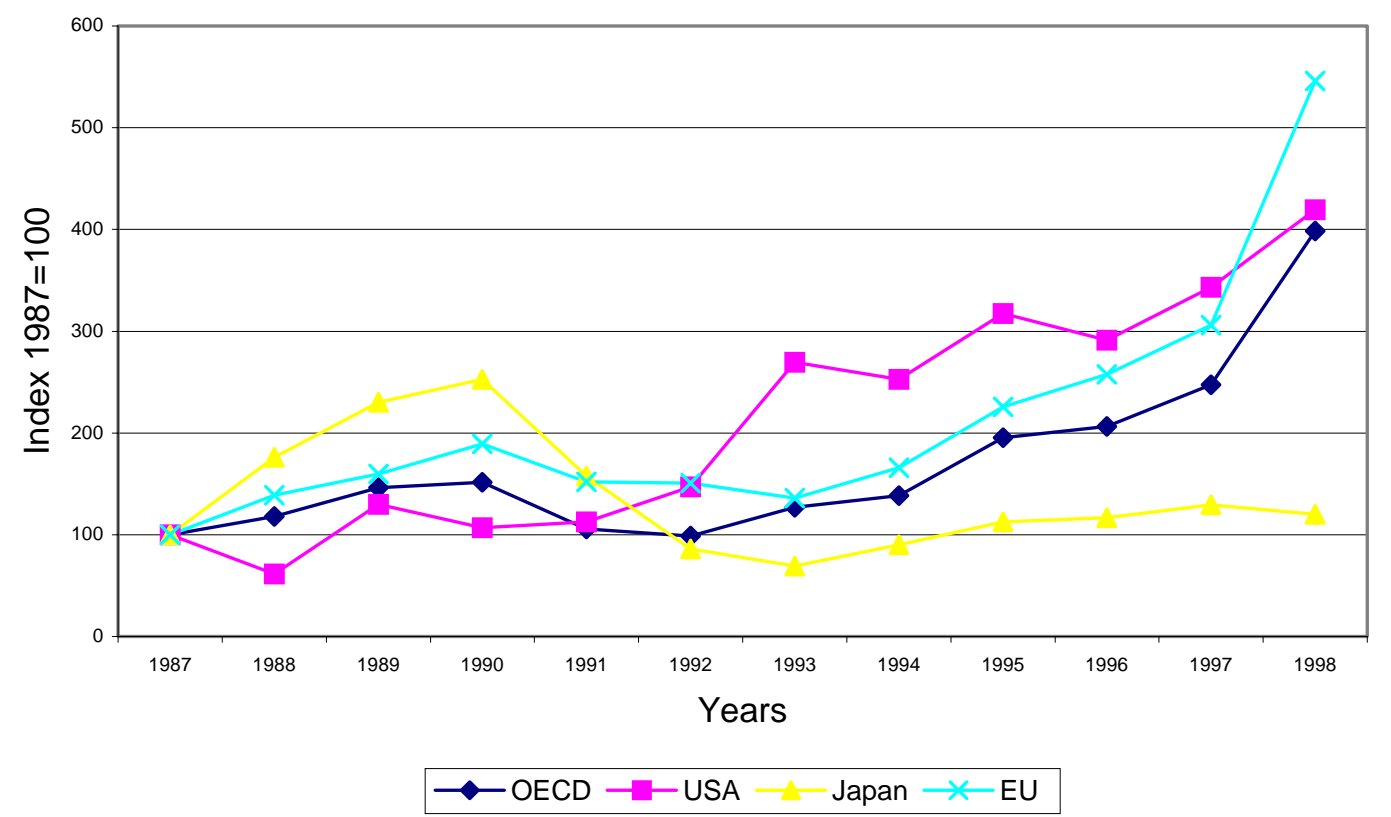

Source: IMF Balance of payments statistics (2000) 
Figure 2: Foreign Direct Investment Inflows

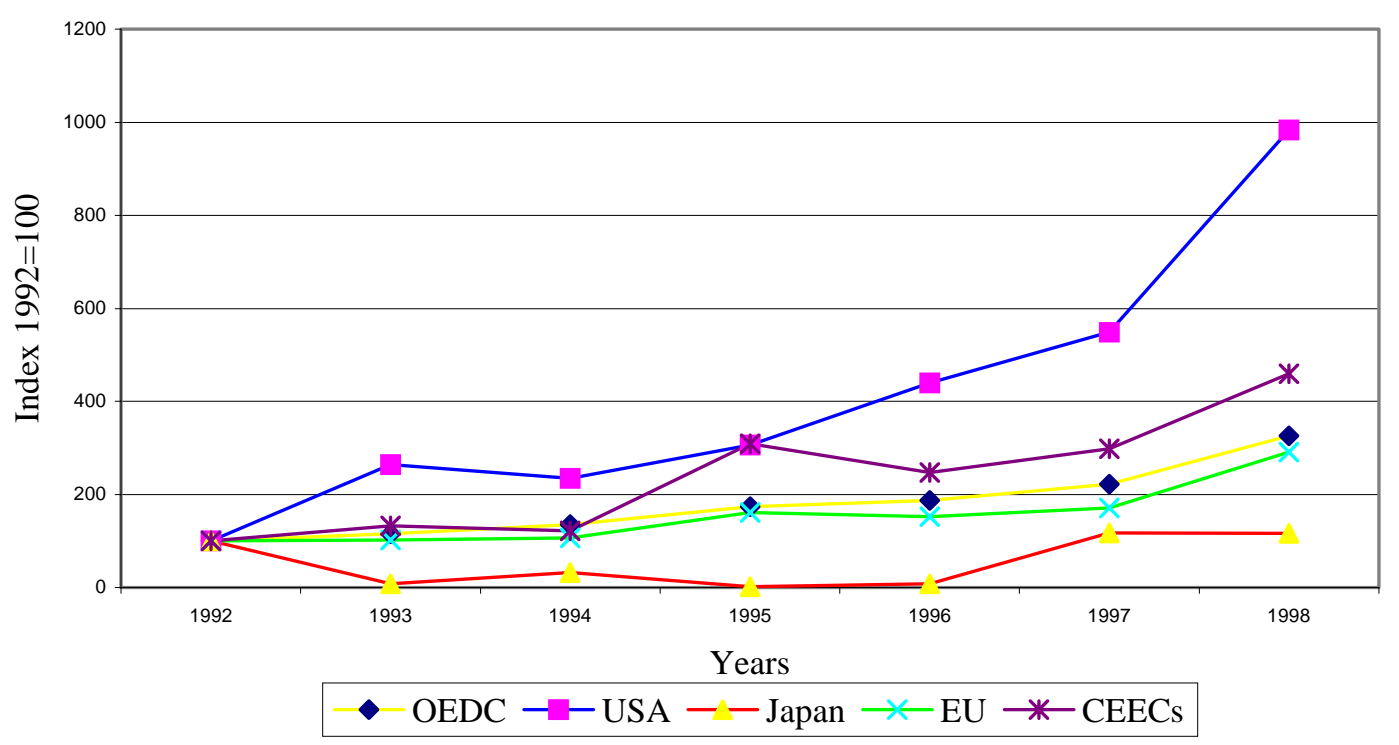

Source: IMF Balance of payments statistics (2000) 
Figure 3: Central and Eastern Europe Foreign Direct Investment Inflows

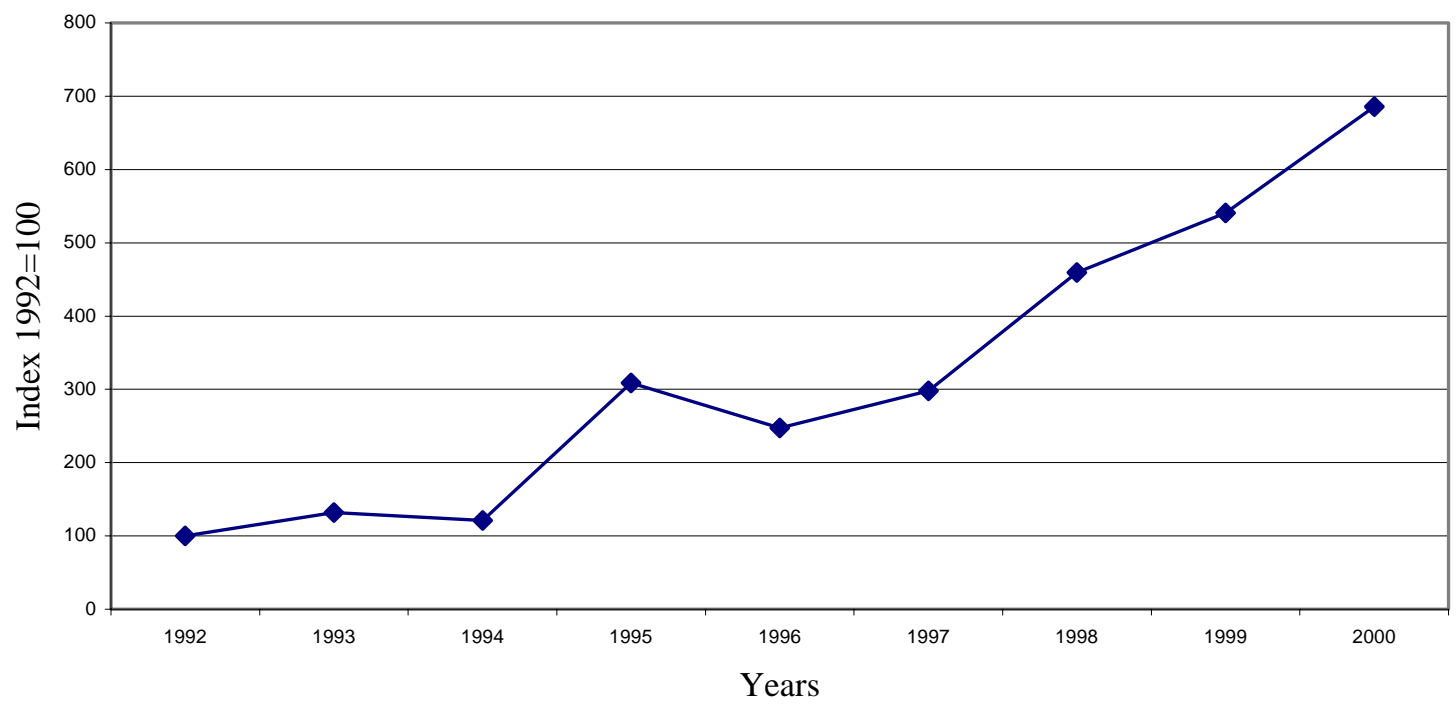

$\multimap$ CEEC FDI Inflows

Source: IMF Balance of payments statistics (2000) 


\section{References}

Abraham, F. and J. Konings, 1999. Does the Opening of Central and Eastern Europe Kill Jobs in the West? World Economy, Vol.22, pp. 585-603.

Arellano, M. and S. Bond, 1991. Some Tests of Specification for Panel Data: Monte Carlo Evidence and an Application to Employment Equations. The Review of Economic Studies, 58, pp. 277-297.

Baldwin, R.E. and G. Cain, 2000. Shifts in US Wages: The Role of Trade, Technology and Factor Endowments. The Review of Economics and Statistics, 82 (4), pp. 580-595.

Bevan, A.A and Estrin, S.,2000. The Determinants of Foreign Direct Investment in Transition Economies. CEPR discussion paper 2638

Bhagwati, J., 1991. Free Traders and Free Immigrationists: Strangers or Friends? Russel Sage Foundation, Working Paper 1991.

Blomstrom, M., G. Fors, and R.E. Lipsey, 1997. Foreign Direct Investment and Employment: Home Country Experience in the United States and Sweden. The Economic Journal, 107 (November), pp. 1787-1797.

Braconier, H. and K. Ekholm, 1999. Swedish Multinationals and Competition from High- and Low-Wage Locations. The Centre for Economic Policy Research, Discussion Paper no. 2323.

Brainard, S.L. and D.A. Riker, 1997. Are U.S. Multinationals Exporting U.S. Jobs? The National Bureau of Economic Research, Working Paper no. 5958.

Bruno, G. and A.M. Falzoni, 2000. Multinational Corporations, Wages and Employment: Do Adjustment Costs Matter? The Centre for Economic Policy Research, Working Paper no. 2471. 
Feenstra, R.C. and G. Hanson, 1995. Foreign Investment, Outsourcing and Relative Wages. In Robert C. Feenstra, Gene M. Grossman, and Douglas A. Irwin, (eds.) Political Economy of Trade Policy: Essays in Honour of Jagdish Bhagwati. Cambridge: MIT Press, pp. 89-127.

Freeman, R.B. and L.F. Katz, 1991. Industrial Wage and Employment Determination in an Open Economy. In John M. Abowd and Richard Freeman, (eds.) Immigration, Trade and the Labour Market. Chicago: University of Chicago Press, pp. 235-259.

Grossman, G.M., 1986. Imports as a Cause of Injury: The Case of the U.S. Steel Industry. Journal of International Economics, 20, pp. 201-223.

Grossman, G.M., 1987. The Employment and Wage Effects of Import Competition. Journal of International Economic Integration, II, pp. 1-23.

Harrigan, J. and R.J. Balaban 1997. U.S. Wages in General Equilibrium: Estimating the Effects of Trade, Technology, and Factor Supplies, 1963-1991. The National Bureau of Economic Research, Working Paper no. 6981.

Hatzius, J., 1998. Domestic Jobs and Foreign Wages. The Scandinavian Journal of Economics, 100 (4), pp. 733-746.

Hine, R.C. and P.W. Wright, 1998. Trade with Low Wage Economies, Employment and Productivity in UK Manufacturing, Economic Journal, 108, pp. 1500-1510.

Johnson, G.E. and F.P. Stafford, 1998. Technology Regimes and the Distribution of Real Wages. In Gunnar Eliasson and Christopher Green (eds.) Microfoundations of Economic Growth: A Schumpeterian Perspective. Ann Arbor: University of Michigan Press.

Krueger, A.B., 1997. Labour Market Shifts and The Price Puzzle Revisited. The National Bureau of Economic Research, Working Paper no. 5924. 
Lankes, H.P. and Venables, A.J. (1996). Foreign Direct Investment in Economic Transition: The Changing Pattern of Investments. Economics of Transition, Vol. 4, pp. 331-347.

Lawrence, R.Z. and M.J. Slaughter, 1993. International Trade and American Wages in the 1980s: Giant Sucking Sound or Small Hiccup? In Martin Neil Baily and Clifford Winston (eds.) Brookings Papers on Economic Activity: Microeconomics 2, 1993, pp. 161-211.

Leamer, E.E., 1998. In Search of Stolper-Samuelson Linkages Between International Trade and Lower Wages. In Susan Collins (ed.) Imports, Exports, and the American Worker. Washington D.C.: Brookings Institution Press, pp. 141-214.

Markusen, J.R 1995. The Boundaries of Multinational Enterprises and the Theory of International Trade. Journal of Economic Perspectives, Vol. 9, nr. 2, pp. 169-189.

Navaretti, G.B., A.M. Falzoni, and A. Turrini, 2000. The Decision to Invest in a LowWage Country: Evidence from Italian Textiles and Clothing Multinationals. The Centre for Economic Policy Research, Discussion Paper no. 2395.

Revenga, A.L., 1992. Exporting Jobs?: The Impact of Import Competition on Employment and Wages in U.S. Manufacturing. Quarterly Journal of Economics, 107 (1), pp. 255-284.

Roland, G., 2000. Transition and Economics: Politics, Markets and Firms. London: MIT Press.

Sachs, J.D. and H. Shatz, 1994. Trade and Jobs in U.S. Manufacturing. Brookings Papers on Economic Activity, pp. 1-84.

Slaughter, M.J., 1998. International Trade and Labour Market Outcomes: Results, Questions and Policy Options. Economic Journal, 108, pp. 1452-1462. 
Slaughter, M.J., 2000. Production Transfer within Multinational Enterprises and American Wages. Journal of International Economics, 50, pp. 449-472. 
Acknowledgements:

This research is supported by the Flemish Government, PBO grant on EU enlargement. We thank Filip Abraham, Peter Neary, Jan Svejnar, Kathy Terrell, Hylke Vandenbussche, Marno Verbeek, Reinhilde Veugelers, Paul Walsh, Ciarra Whelan and Leo Sleuwaegen for valuable comments and discussions. This paper benefited from presentations at LICOS, K.U.Leuven, the William Davidson Institute at the Univ. of Michigan Ann Arbor, University College Dublin and Trinity College Dublin. 


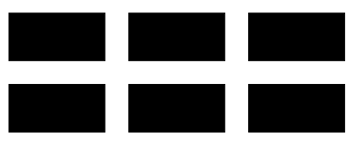

THE WILLIAM DAVIDSON INSTITUTE

AT THE UNIVERSITY OF MICHIGAN BUSINESSSCHOOL

\section{DAVIDSON INSTITUTE WORKING PAPER SERIES - Most Recent Papers}

The entire Working Paper Series is available at: www.wdi.bus.umich.edu

CURRENT AS OF 4/24/01

\begin{tabular}{|c|c|c|}
\hline Publication & Authors & Date \\
\hline $\begin{array}{l}\text { No. } 371 \text { Do Multinational Enterprises Substitute Parent Jobs for Foreign } \\
\text { One? Evidence from Firm Level Panel Data }\end{array}$ & Jozef Konings & Apr. 2001 \\
\hline $\begin{array}{l}\text { No. } 370 \text { From Needs to the Market: Changing Inequality of Household } \\
\text { Income in the Czech Transition }\end{array}$ & Jiri Vecernik & Apr. 2001 \\
\hline $\begin{array}{l}\text { No. } 369 \text { Competition and Corporate Governance: Substitutes or } \\
\text { Complements? Evidence from the Warsaw Stock Exchange }\end{array}$ & $\begin{array}{l}\text { Irena Grosfeld and Thierry } \\
\text { Tressel }\end{array}$ & Mar. 2001 \\
\hline $\begin{array}{l}\text { No. } 368 \text { Multinational Corporations as Catalyst for Industrial } \\
\text { Development: The Case of Poland }\end{array}$ & $\begin{array}{l}\text { Carlo Altomonte and Laura } \\
\text { Resmini }\end{array}$ & Feb. 2001 \\
\hline No. 367 A Multi-Task Theory of the State Enterprise Reform & $\begin{array}{l}\text { Chong-En Bai, David D. Li, } \\
\text { Zhigang Tao, and Yijiang Wang }\end{array}$ & Mar. 2001 \\
\hline No. 366 Confidence Building in Emerging Stock Markets & $\begin{array}{l}\text { Enrico C. Perotti, Luc Laeven, } \\
\text { and Pieter van Oijen }\end{array}$ & 2000 \\
\hline $\begin{array}{l}\text { No. } 365 \text { Incentive Contracting versus Ownership Reforms: Evidence } \\
\text { from China's Township and Village Enterprises }\end{array}$ & $\begin{array}{l}\text { Chun Chang, Brian McCall, and } \\
\text { Yijang Wang }\end{array}$ & Nov. 2000 \\
\hline $\begin{array}{l}\text { No. } 364 \text { Individual Pay and Outside Options: Evidence from the Polish } \\
\text { Labour Force Survey }\end{array}$ & $\begin{array}{l}\text { Fiona Duffy and Patrick Paul } \\
\text { Walsh }\end{array}$ & Mar. 2001 \\
\hline $\begin{array}{l}\text { No. } 363 \text { Investment, Credit Rationing and the Soft Budget Constraint: } \\
\text { Evidence from Czech Panel Data (revised Davidson Institute Working } \\
\text { Paper No. 60a) }\end{array}$ & Lubomír Lízal and Jan Svejnar & Feb. 2001 \\
\hline $\begin{array}{l}\text { No. } 362 \text { A Network Perspective on Inter-Organizational Transfer of } \\
\text { R\&D Capabilities: A Study of International Joint Ventures in Chinese } \\
\text { Automobile Industry }\end{array}$ & $\begin{array}{l}\text { Zheng Zhao, Jaideep Anand and } \\
\text { Will Mitchell }\end{array}$ & Feb. 2001 \\
\hline $\begin{array}{l}\text { No. } 361 \text { Network Restructuring and Firm Creation in East-Central } \\
\text { Europe: A Public-Private Venture }\end{array}$ & Gerald A. McD & Dec. 2000 \\
\hline $\begin{array}{l}\text { No. } 360 \text { Responses of Private and Public Schools to Voucher Funding: } \\
\text { The Czech and Hungarian Experience }\end{array}$ & $\begin{array}{l}\text { Randall K. Filer and Daniel } \\
\text { Münich }\end{array}$ & Oct. 2000 \\
\hline $\begin{array}{l}\text { No. } 359 \text { Labor Market Uncertainty and Private Sector Labor Supply in } \\
\text { Russia }\end{array}$ & Steven Stillman & Sept. 2000 \\
\hline $\begin{array}{l}\text { No. } 358 \text { Russian Roulette-Expenditure Inequality and Instability in } \\
\text { Russia, 1994-1998 }\end{array}$ & Branko Jovanovic & Sept. 2000 \\
\hline No. 357 Dealing with the Bad Loans of the Chinese Banks & John P. Bonin and Yiping Huang & Jan. 2001 \\
\hline No. 356 Retail Banking in Hungary: A Foreign Affair? & John P. Bonin and István Ábel & Dec. 2000 \\
\hline $\begin{array}{l}\text { No. } 355 \text { Optimal Speed of Transition: Micro Evidence from the Czech } \\
\text { Republic }\end{array}$ & $\begin{array}{l}\text { Stepan Jurajda and Katherine } \\
\text { Terrell }\end{array}$ & Dec. 2000 \\
\hline No. 354 Political Instability and Growth in Dictatorships & $\begin{array}{l}\text { Jody Overland, Kenneth L. } \\
\text { Simons and Michael Spagat }\end{array}$ & Nov. 2000 \\
\hline No. 353 Disintegration and Trade & Jarko Fidrmuc and Jan Fidrmuc & Nov. 2000 \\
\hline $\begin{array}{l}\text { No. } 352 \text { Social Capital and Entrepreneurial Performance in Russia: A } \\
\text { Panel Study }\end{array}$ & Bat Batjargal & Dec. 2000 \\
\hline $\begin{array}{l}\text { No. } 351 \text { Entrepreneurial Versatility, Resources and Firm Performance in } \\
\text { Russia: A Panel Study }\end{array}$ & Bat Batjargal & Dec. 2000 \\
\hline $\begin{array}{l}\text { No. } 350 \text { The Dynamics of Entrepreneurial Networks in a Transitional } \\
\text { Economy: The Case of Russia }\end{array}$ & Bat Batjargal & Dec. 2000 \\
\hline
\end{tabular}




\begin{tabular}{|c|c|c|}
\hline $\begin{array}{l}\text { No. } 349 \text { R\&D and Technology Spillovers via FDI: Innovation and } \\
\text { Absorptive Capacity }\end{array}$ & Yuko Kinoshita & Nov. 2000 \\
\hline $\begin{array}{l}\text { No. } 348 \text { Microeconomic aspects of Economic Growth in Eastern } \\
\text { Europe and the Former Soviet Union, 1950-2000 }\end{array}$ & Sergei Guriev and Barry W. Ickes & Nov. 2000 \\
\hline $\begin{array}{l}\text { No. } 347 \text { Effective versus Statutory Taxation: Measuring Effective Tax } \\
\text { Administration in Transition Economies }\end{array}$ & $\begin{array}{l}\text { Mark E. Schaffer and Gerard } \\
\text { Turley }\end{array}$ & Nov. 2000 \\
\hline $\begin{array}{l}\text { No. } 346 \text { Objectives and Constraints of Entrepreneurs: Evidence from } \\
\text { Small and Medium Size Enterprises in Russia and Bulgaria }\end{array}$ & $\begin{array}{l}\text { Francesca Pissarides, Miroslav } \\
\text { Singer and Jan Svejnar }\end{array}$ & Oct. 2000 \\
\hline No. 345 Corruption and Anticorruption in the Czech Republic & $\begin{array}{l}\text { Lubomír Lízal and Evžen } \\
\text { Kočenda }\end{array}$ & Oct. 2000 \\
\hline No. 344 The Effects of Direct Foreign Investment on Domestic Firms & Jozef Konings & Oct. 2000 \\
\hline No. 343 On the Identification of Relative Wage Rigidity Dynamics & Patrick A. Puhani & Oct. 2000 \\
\hline $\begin{array}{l}\text { No. } 342 \text { The Determinants of Foreign Direct Investment in Transition } \\
\text { Economies }\end{array}$ & Alan A. Bevan and Saul Estrin & Oct. 2000 \\
\hline No. 341 The Global Spread of Stock Exchanges, 1980-1998 & Klaus Weber and Gerald F. Davis & Nov. 2000 \\
\hline $\begin{array}{l}\text { No. } 340 \text { The Costs and Benefits of Euro-isation in Central-Eastern } \\
\text { Europe Before or Instead of EMU Membership }\end{array}$ & D. Mario Nuti & Oct. 2000 \\
\hline No. 339 Debt Overhang and Barter in Russia & $\begin{array}{l}\text { Sergei Guriev, Igor Makarov and } \\
\text { Mathilde Maurel }\end{array}$ & Sept. 2000 \\
\hline $\begin{array}{l}\text { No. } 338 \text { Firm Performance and the Political Economy of Corporate } \\
\text { Governance: Survey Evidence for Bulgaria, Hungary, Slovakia and } \\
\text { Slovenia }\end{array}$ & $\begin{array}{l}\text { Patrick Paul Walsh and Ciara } \\
\text { Whela }\end{array}$ & July 2000 \\
\hline No. 337 Investment and Instability & $\begin{array}{l}\text { Nauro F. Campos a } \\
\text { Nugent }\end{array}$ & May 2000 \\
\hline $\begin{array}{l}\text { No. } 336 \text { The Evolution of the Insurance Sector in Central and } \\
\text { Eastern Europe and the former Soviet Union }\end{array}$ & Robert B.K. Pye & Aug. 2000 \\
\hline $\begin{array}{l}\text { No. } 335 \text { Institutional Technology and the Chains of Trust: Capital } \\
\text { Markets and Privatization in Russia and the Czech Republic }\end{array}$ & Bruce K & Aug. 2000 \\
\hline No. 334 The Evolution of Market Integration in Russia & $\begin{array}{l}\text { Daniel Berkowitz and David N. } \\
\text { DeJong }\end{array}$ & Aug. 2000 \\
\hline No. 333 Efficiency and Market Share in Hungarian Corporate Sector & László Halpern and Gábor Körösi & July 2000 \\
\hline No. 332 Search-Money-and-Barter Models of Financial Stabilization & $\begin{array}{l}\text { S.I. Boyarchenko and S.Z. } \\
\text { Levendorskii }\end{array}$ & July 2000 \\
\hline $\begin{array}{l}\text { No. } 331 \text { Worker Training in a Restructuring Economy: Evidence from } \\
\text { the Russian Transition }\end{array}$ & $\begin{array}{l}\text { Mark C. Berger, John S. Earle } \\
\text { and Klara Z. Sabirianova }\end{array}$ & Aug. 2000 \\
\hline $\begin{array}{l}\text { No. } 330 \text { Economic Development in Palanpur 1957-1993: A Sort of } \\
\text { Growth }\end{array}$ & Peter Lanjouw & Aug. 2000 \\
\hline $\begin{array}{l}\text { No. } 329 \text { Trust, Organizational Controls, Knowledge Acquisition from } \\
\text { the Foreign Parents, and Performance in Vietnamese International Joint } \\
\text { Ventures }\end{array}$ & $\begin{array}{l}\text { Marjorie A. Lyles, Le Dang } \\
\text { Doanh, and Jeffrey Q. Barden }\end{array}$ & June 2000 \\
\hline $\begin{array}{l}\text { No. } 328 \text { Comparative Advertising in the Global Marketplace: The } \\
\text { Effects of Cultural Orientation on Communication }\end{array}$ & $\begin{array}{l}\text { Zeynep Gürhan-Canli and } \\
\text { Durairaj Maheswaran }\end{array}$ & Aug. 2000 \\
\hline No. 327 Post Privatization Enterprise Restructuring & Morris Bornstein & July 2000 \\
\hline No. 326 Who is Afraid of Political Instability? & $\begin{array}{l}\text { Nauro F. Campos and Jeffrey B. } \\
\text { Nugent }\end{array}$ & July 2000 \\
\hline No. 325 Business Groups, the Financial Market and Modernization & Raja Kali & June 2000 \\
\hline $\begin{array}{l}\text { No. } 324 \text { Restructuring with What Success? A Case Study of Russian } \\
\text { Firms }\end{array}$ & Susan Linz & July 2000 \\
\hline $\begin{array}{l}\text { No. } 323 \text { Priorities and Sequencing in Privatization: Theory and } \\
\text { Evidence from the Czech Republic }\end{array}$ & $\begin{array}{l}\text { Nandini Gupta, John C. Ham and } \\
\text { Jan Svejnar }\end{array}$ & May 2000 \\
\hline $\begin{array}{l}\text { No. } 322 \text { Liquidity, Volatility, and Equity Trading Costs Across } \\
\text { Countries and Over Time }\end{array}$ & $\begin{array}{l}\text { Ian Domowitz, Jack Glen and } \\
\text { Ananth Madhavan }\end{array}$ & Mar. 2000 \\
\hline $\begin{array}{l}\text { No. } 321 \text { Equilibrium Wage Arrears: A Theoretical and Empirical } \\
\text { Analysis of Institutional Lock-In }\end{array}$ & $\begin{array}{l}\text { John S. Earle and Klara Z. } \\
\text { Sabirianova }\end{array}$ & Oct. 2000 \\
\hline No. 320 Rethinking Marketing Programs for Emerging Markets & $\begin{array}{l}\text { Niraj Dawar and Amitava } \\
\text { Chattopadhyay }\end{array}$ & June 2000 \\
\hline
\end{tabular}


No. 319 Public Finance and Low Equilibria in Transition Economies: the Role of Institutions

No. 318 Some Econometric Evidence on the Effectiveness of Active Labour Market Programmes in East Germany

No. 317 A Model of Russia's "Virtual Economy"

No. 316 Financial Institutions, Financial Contagion, and Financial Crises

No. 315 Privatization versus Regulation in Developing Economies: The Case of West African Banks

No. 314 Is Life More Risky in the Open? Household Risk-Coping and the Opening of China's Labor Markets

No. 313 Networks, Migration and Investment: Insiders and Outsiders in Tirupur's Production Cluster

No. 312 Computational Analysis of the Impact on India of the Uruguay Round and the Forthcoming WTO Trade Negotiations

No. 311 Subsidized Jobs for Unemployed Workers in Slovakia No. 310 Determinants of Managerial Pay in the Czech Republic

No. 309 The Great Human Capital Reallocation: An Empirical Analysis of Occupational Mobility in Transitional Russia

No. 308 Economic Development, Legality, and the Transplant Effect

No. 307 Community Participation, Teacher Effort, and Educational Outcome: The Case of El Salvador's EDUCO Program

No. 306 Gender Wage Gap and Segregation in Late Transition No. 305 The Gender Pay Gap in the Transition from Communism: Some Empirical Evidence

No. 304 Post-Unification Wage Growth in East Germany

No. 303 How Does Privatization Affect Workers? The Case of the

Russian Mass Privatization Program

No. 302 Liability for Past Environmental Contamination and Privatization

No. 301 Varieties, Jobs and EU Enlargement

No. 300 Employer Size Effects in Russia

No. 299 Information Complements, Substitutes, and Strategic Product Design

No. 298 Markets, Human Capital, and Inequality: Evidence from Rural China

No. 297 Corporate Governance in the Asian Financial Crisis

No. 296 Competition and Firm Performance: Lessons from Russia No. 295 Wage Determination in Russia: An Econometric Investigation

No. 294 Can Banks Promote Enterprise Restructuring?: Evidence From a Polish Bank's Experience

No. 293 Why do Governments Sell Privatised Companies Abroad?

No. 292 Going Public in Poland: Case-by-Case Privatizations, Mass Privatization and Private Sector Initial Public Offerings

No. 291a Institutional Technology and the Chains of Trust: Capital Markets and Privatization in Russia and the Czech Republic

No. 291 Institutional Technology and the Chains of Trust: Capital

Markets and Privatization in Russia and the Czech Republic

\begin{tabular}{|c|c|}
\hline $\begin{array}{l}\text { Daniel Daianu and Radu } \\
\text { Vranceanu }\end{array}$ & June 2000 \\
\hline $\begin{array}{l}\text { Martin Eichler and Michael } \\
\text { Lechner }\end{array}$ & June 2000 \\
\hline R.E Ericson and B.W Ickes & May 2000 \\
\hline $\begin{array}{l}\text { Haizhou Huang and Chenggang } \\
\mathrm{Xu}\end{array}$ & Mar. 2000 \\
\hline $\begin{array}{l}\text { Jean Paul Azam, Bruno Biais, and } \\
\text { Magueye Dia }\end{array}$ & Feb. 2000 \\
\hline John Giles & Apr. 2000 \\
\hline $\begin{array}{l}\text { Abhijit Banerjee and Kaivan } \\
\text { Munshi }\end{array}$ & Mar. 2000 \\
\hline $\begin{array}{l}\text { Rajesh Chadha, Drusilla K. } \\
\text { Brown, Alan V. Deardorff and } \\
\text { Robert M. Stern }\end{array}$ & Mar. 2000 \\
\hline Jan. C. van Ours & May 2000 \\
\hline $\begin{array}{l}\text { Tor Eriksson, Jaromir Gottvald } \\
\text { and Pavel Mrazek }\end{array}$ & May 2000 \\
\hline Klara Z. Sabirianova & Oct. 2000 \\
\hline $\begin{array}{l}\text { Daniel Berkowitz, Katharina } \\
\text { Pistor, and Jean-Francois Richard }\end{array}$ & Feb. 2000 \\
\hline Yasuyuki Sawada & Nov. 1999 \\
\hline Stepan Jurajda & May 2000 \\
\hline Andrew Newell and Barry Reilly & May 2000 \\
\hline Jennifer Hunt & Nov. 1998 \\
\hline Elizabeth Brainerd & May 2000 \\
\hline Dietrich Earnhart & Mar. 2000 \\
\hline $\begin{array}{l}\text { Tito Boeri and Joaquim Oliveira } \\
\text { Martins }\end{array}$ & May 2000 \\
\hline Todd Idson & Apr. 2000 \\
\hline $\begin{array}{l}\text { Geoffrey G. Parker and Marshall } \\
\text { W. Van Alstyne }\end{array}$ & Mar. 2000 \\
\hline $\begin{array}{l}\text { Dwayne Benjamin, Loren Brandt, } \\
\text { Paul Glewwe, and Li Guo }\end{array}$ & May 2000 \\
\hline $\begin{array}{l}\text { Simon Johnson, Peter Boone, } \\
\text { Alasdair Breach, and Eric } \\
\text { Friedman }\end{array}$ & Nov. 1999 \\
\hline J. David Brown and John S. Earle & Mar. 2000 \\
\hline $\begin{array}{l}\text { Peter J. Luke and Mark E. } \\
\text { Schaffer }\end{array}$ & Mar. 2000 \\
\hline John P. Bonin and Bozena Leven & Mar. 2000 \\
\hline $\begin{array}{l}\text { Bernardo Bortolotti, Marcella } \\
\text { Fantini and Carlo Scarpa }\end{array}$ & Mar. 2000 \\
\hline Wolfgang Aussenegg & Dec. 1999 \\
\hline Bruce Kogut and Andrew Spicer & Feb. 2001 \\
\hline Bruce Kogut and Andrew Spicer & Mar. 1999 \\
\hline
\end{tabular}




\begin{tabular}{|c|c|c|}
\hline No. 290 Banking Crises and Bank Rescues: The Effect of Reputation & Jenny Corbett and Janet Mitchell & Jan. 2000 \\
\hline $\begin{array}{l}\text { No. } 289 \text { Do Active Labor Market Policies Help Unemployed Workers to } \\
\text { Find and Keep Regular Jobs? }\end{array}$ & Jan C. van Ours & Feb. 2000 \\
\hline No. 288 Consumption Patterns of the New Elite in Zimbabwe & Russell Belk & Feb. 2000 \\
\hline $\begin{array}{l}\text { No. } 287 \text { Barter in Transition Economies: Competing Explanations } \\
\text { Confront Ukranian Data }\end{array}$ & $\begin{array}{l}\text { Dalia Marin, Daniel Kaufmann } \\
\text { and Bogdan Gorochowskij }\end{array}$ & Jan. 2000 \\
\hline $\begin{array}{l}\text { No. } 286 \text { The Quest for Pension Reform: Poland's Security through } \\
\text { Diversity }\end{array}$ & $\begin{array}{l}\text { Marek Góra and Michael } \\
\text { Rutkowski }\end{array}$ & Jan. 2000 \\
\hline No. 285 Disorganization and Financial Collapse & $\begin{array}{l}\text { Dalia Marin and Monika } \\
\text { Schnitzer }\end{array}$ & Oct. 1999 \\
\hline No. 284 Coordinating Changes in M-form and U-form Organizations & $\begin{array}{l}\text { Yingyi Qian, Gérard Roland and } \\
\text { Chenggang Xu }\end{array}$ & May 1999 \\
\hline $\begin{array}{l}\text { No. } 283 \text { Why Russian Workers Do Not Move: Attachment of Workers } \\
\text { Through In-Kind Payments }\end{array}$ & Guido Friebel and Sergei Guriev & Oct. 1999 \\
\hline No. 282 Lessons From Fiascos in Russian Corporate Governance & $\begin{array}{l}\text { Merritt B. Fox and Michael A. } \\
\text { Heller }\end{array}$ & Oct. 1999 \\
\hline $\begin{array}{l}\text { No. } 281 \text { Income Distribution and Price Controls: Targeting a Social } \\
\text { Safety Net During Economic Transition }\end{array}$ & $\begin{array}{l}\text { Michael Alexeev and James } \\
\text { Leitzel }\end{array}$ & Mar. 1999 \\
\hline $\begin{array}{l}\text { No. 280: Starting Positions, Reform Speed, and Economic Outcomes in } \\
\text { Transitioning Economies }\end{array}$ & William Hallagan and Zhang Jun & Jan. 2000 \\
\hline No. 279: The Value of Prominent Directors & $\begin{array}{l}\text { Yoshiro Miwa \& J. Mark } \\
\text { Ramseyer }\end{array}$ & Oct. 1999 \\
\hline No. 278: The Sy & János Kornai & Apr. 1998 \\
\hline $\begin{array}{l}\text { No. 277: The Developmental Consequences of Foreign Direct } \\
\text { Investment in the Transition from Socialism to Capitalism: The } \\
\text { Performance of Foreign Owned Firms in Hungary }\end{array}$ & Lawrence Peter King & Sept. 1999 \\
\hline $\begin{array}{l}\text { No. 276: Stability and Disorder: An Evolutionary Analysis of Russia's } \\
\text { Virtual Economy }\end{array}$ & $\begin{array}{l}\text { Clifford Gaddy and Barry W. } \\
\text { Ickes }\end{array}$ & Nov. 1999 \\
\hline $\begin{array}{l}\text { No. 275: Limiting Government Predation Through Anonymous } \\
\text { Banking: A Theory with Evidence from China. }\end{array}$ & $\begin{array}{l}\text { Chong-En Bai, David D. Li, } \\
\text { Yingyi Qian and Yijiang Wang }\end{array}$ & July 1999 \\
\hline No. 274: Transition with Labour Supply & Tito Boeri & Dec. 1999 \\
\hline $\begin{array}{l}\text { No. 273: Sectoral Restructuring and Labor Mobility: A Comparative } \\
\text { Look at the Czech Republic }\end{array}$ & Vit Sorm and Katherine Terrell & Nov. 1999 \\
\hline $\begin{array}{l}\text { No. 272: Published in: Journal of Comparative Economics "Returns to } \\
\text { Human Capital Under the Communist Wage Grid and During the } \\
\text { Transition to a Market Economy" Vol. 27, pp. 33-60 } 1999 .\end{array}$ & $\begin{array}{l}\text { Daniel Munich, Jan Svejnar and } \\
\text { Katherine Terrell }\end{array}$ & Oct. 1999 \\
\hline $\begin{array}{l}\text { No. 271: Barter in Russia: Liquidity Shortage Versus Lack of } \\
\text { Restructuring }\end{array}$ & $\begin{array}{l}\text { Sophie Brana and Mathilde } \\
\text { Maurel }\end{array}$ & June 1999 \\
\hline $\begin{array}{l}\text { No. 270: Tests for Efficient Financial Intermediation with Application to } \\
\text { China }\end{array}$ & Albert Park and Kaja Sehrt & Mar. 1999 \\
\hline $\begin{array}{l}\text { No. 269a: Russian Privatization and Corporate Governance: What Went } \\
\text { Wrong? }\end{array}$ & $\begin{array}{l}\text { Bernard Black, Reinier Kraakman } \\
\text { and Anna Tarassova }\end{array}$ & May 2000 \\
\hline $\begin{array}{l}\text { No. 269: Russian Privatization and Corporate Governance: What Went } \\
\text { Wrong? }\end{array}$ & $\begin{array}{l}\text { Bernard Black, Reinier Kraakman } \\
\text { and Anna Tarassova }\end{array}$ & Sept. 1999 \\
\hline No. 268: Are Russians Really Ready for Capitalism? & Susan Linz & Sept. 1999 \\
\hline No. 267: Do Stock Markets Promote Economic Growth? & $\begin{array}{l}\text { Randall K. Filer, Jan Hanousek } \\
\text { and Nauro Campos }\end{array}$ & Sept. 1999 \\
\hline $\begin{array}{l}\text { No. 266: Objectivity, Proximity and Adaptability in Corporate } \\
\text { Governance }\end{array}$ & $\begin{array}{l}\text { Arnoud W.A Boot and Jonathan } \\
\text { R. Macey }\end{array}$ & Sept. 1999 \\
\hline $\begin{array}{l}\text { No. 265: When the Future is not What it Used to Be: Lessons from the } \\
\text { Western European Experience to Forecasting Education and Training in } \\
\text { Transitional Economies }\end{array}$ & $\begin{array}{l}\text { Nauro F. Campos, Gerard } \\
\text { Hughes, Stepan Jurajda, and } \\
\text { Daniel Munich }\end{array}$ & Sept. 1999 \\
\hline $\begin{array}{l}\text { No. 264: The Institutional Foundation of Foreign-Invested Enterprises } \\
\text { (FIEs) in China }\end{array}$ & Yasheng Huang & Sept. 1999 \\
\hline $\begin{array}{l}\text { No. 263: The Changing Corporate Governance Paradigm: Implications } \\
\text { for Transition and Developing Countries }\end{array}$ & $\begin{array}{l}\text { Erik Berglof and Ernst-Ludwig } \\
\text { von Thadden }\end{array}$ & June 1999 \\
\hline
\end{tabular}

